\title{
The Influence of Discovery Learning Model on Conceptual Understanding and Self-Efficacy of Students at Vocational High School
}

\author{
Hendrik \\ The student of Graduated Program \\ Unimed \\ Medan, Indonesia \\ hendrikmtk@yahoo.com \\ Ani Minarni \\ Graduated Program \\ Unimed \\ Medan, Indonesia
}

\begin{abstract}
Problems in this research is students' difficulty within solving conceptual understanding problems. It is caused by teachers are still using many conventional methods and Discovery Learning model used by teachers is not in accordance with the expected procedure. This research is quasi-experimental in form of non-equivalent control group design. Population in this research is all student of $10^{\text {th }}$ grade of vocational high School Sinar Husni. Randomly, TKJ 3 X class selected as Experiment class treated by Discovery Learning model and TKJ $1 \mathrm{X}$ class as Control Class is treated by conventional approach. The used instruments consisted of early math skills tests, conceptual understanding skills tests and self-efficacy questionnaires. The instrument is stated to have fulfilled the validity and reliability. Data analysis was performed using Mann Whitney $U$ test, Two Path ANOVA and One Path ANAVA. The results showed that the improvement of conceptual understanding ability and students' Self Efficacy who were given Discovery Learning Model was significantly better compared to the students who were given the conventional approach. In addition, there is a difference in the improvement of ability to understand the concept between high, medium, and low for students who are given Discovery Learning Model, where as there is no difference in students' Self Efficacy improvement.
\end{abstract}

Keywords: Discovery Learning Model, conceptual understanding, Self Efficacy

\section{INTRODUCTION}

The mathematics is the science with the concepts is arranged in a hierarchical, structured, logical and systematic ranging from the simplest concept to the most complex concept. For that, learning math must be done continuously, meaning continuous and not intermittent. Hudojo According to, "The concepts in mathematics have interrelationships with one another, so students should be given more opportunities to see connections with other materials"[1]. It is intended that students can comprehend math material widely and deeply.

If students are be able to understand the concepts of mathematics deeply, then the next student must have been able to solve the problems and able to apply the learning. Hudojo also revealed that to be able to understand the structures and relationships, of course it takes an understanding of the concepts contained in mathematics[1].

The results of PISA (Program for International Student Assessment)study in 2015 show Indonesia can only rank 69 out of 76 countries. While from the result of TIMSS (Trends in International Mathematics and Science Study) study of Indonesia is ranked 36 out of 49 countries (http://litbang.kemdikbud.go.id/index.php/timss). From this result, it can be concluded that what is taught in Indonesia is different from what is tested or standardized at International level.

That the vision of developing mathematics learning to meet the necessary of the present and future of mathematics learning needs to be directed understanding the concepts and principles of mathematics that are needed to solve mathematics problems as well as other the scientific problems[2]. Thus, it can be said that conceptual understanding plays an important role and needs to be improved in learning mathematics.

In addition to the ability to understand the concept, another aspect that needs to be developed is the student's selfconfidence (self-efficacy). Arends According "The overal goal of inquiry teaching has been, and continues to be, that helping student learn how to ask question, seek answers or solution to satisfy their curiosity, and building their own theories and ideas about the world"[3]. Bandura According self-efficacy as one's beliefs about their ability to produce performance that 
has an influence over their lives. Self-efficacy determines how one feels, thinks, motivates themself and behaves[4]. Selfefficacy has relevance to student achievement and motivation. Someone who has high self-efficacy will improve the achievement and learning outcomes because with a high selfefficacy one will be able to face difficult problems by considering it as a challenge that must be mastered not as a threat to be avoided. On the contrary, someone who has low self-efficacy will doubt their ability and tend to avoid difficult problems so easily give up and lead to failure. In the learning of mathematics if a student feels able to work on a mathematic problem will have an impact on the success of students in solving the problem well. Bandura said that student's belief in their ability to master academic activities affecting their aspirations, their level of interest and academic achievement. Therefore, self-efficacy is an internal factor in the psychology of a student self that affects the beliefs that student have in order to succeed in the learning process. But based on the interview of the writer to one of the mathematics teachers at vocational high school Sinar Husni self-efficacy the students stated that when the learning of mathematics students are less challenged to solve difficult problems, students tend to give up and lazy to solve mathematics problems. Students also tend to be anxious or scared when the teacher asks to present the answers to the front of the class. This makes students less likely to be passive, less motivated and afraid to try to solve the mathematics problems.

This indicates that the student's self-efficacy attitude is low and needs to improve on it, because good self-efficacy will provide good learning motivation also. Boucheyand Harter revealed that a student who has a good mathematics academic self-efficacy in math lessons affects the individual's achievement itself. Thus, it can be said that the self-efficacy of a student is able to support his mathematics ability[5]. Based on the above discussion, the writer is interested to do research about "the influence of the Discovery Learning model on the ability to comprehend the concept of mathematics and student self-efficacy Vocational high School of Sinar Husni student". In accordance with the opinion "Discovery Learning method is one that can be used to achieve the purpose of learning mathematics[6]. same as the opinion of Slamecaand Graf state that "discovery learning is efficacious because such learning involves the discovery and generation of general principles or explanation of domain specific patterns after discovering such as one's own"[7].

The purpose of this study is to know 1) the difference in the ability to understand the concept of mathematics between students who are given a model of Discovery Learning compared with students who are given a the Conventional Approach. 2) The interaction between the learning approach and the student's early mathematics ability towards improving understanding of mathematics concepts. 3) The differences in self-efficacy between students who are given Discovery Learning model compared with students who are given a Conventional Approach. 4) The interaction between the learning model and the student's early mathematical ability to the improvement of mathematical critical thinking.

\section{METHOD}

This study is quasi-experimental with a non-equivalent control group design with pretest-posttest control group design that can be systematically presented in table 1 below: Table 1 (pretest-posttest control group design)

\begin{tabular}{|l|l|l|l|}
\hline Class & Pre-test & Treatment & Post-test \\
\hline $\mathrm{E}$ & $\mathrm{X}_{1}$ & $\mathrm{~T}_{1}$ & $\mathrm{Y}_{1}$ \\
\hline $\mathrm{K}$ & $\mathrm{X}_{2}$ & $\mathrm{~T}_{2}$ & $\mathrm{Y}_{2}$ \\
\hline
\end{tabular}

Explanation:

E: Experiment class,

$\mathrm{K}$ : Control class,

$\mathrm{X}_{1}$ : Experiment group pre-test,

$\mathrm{X}_{2}$ : Control grouppre-test,

$\mathrm{T}_{1}$ : Discovery Learning Model learning,

$\mathrm{T}_{2}$ : Conventional method learning,

$\mathrm{Y}_{1}$ : Experiment group post-test,

$\mathrm{Y}_{2}$ : Control group post-test.

Aims to determine the improvement of the ability to understand the concept and critical thinking of mathematical students, as well as know the problems faced by students in completing the conceptual refinement. The population in this study is the students of $\mathrm{X}$ grade of Computer Engineering and Network department of Vocational high School Sinar Husni, consisting of three classes because the material system of linear equations and inequality is in $\mathrm{X}$ grade of $2^{\text {nd }}$ semester of years of learning 2016/2017. Based on the purposive sampling technique, it is determined that the sample in this study is $\mathrm{X}$ grade of $1^{\text {st }}$ TKJ with the number of students as 31 students as a control group (mathematics learning by conventional method) and $\mathrm{X}$ grade of $3^{\text {rd }}$ TKJ with 31 students as experiment group (mathematics learning by Discovery Learning Model). Data used in this research is pre-test score, post-test score. To obtain data in research used two kinds of instruments that is test. The test instruments are questions that are used to measure the concept's comprehension skillsand the questionnaire to measure self-efficacy.

Test/instrument that used in this research is divided into two kinds of tests, namely pre-test and post-test. Pre-test and post-test are given to students with the same problem instrument. The instrument that used in this research is a description test of 5 questions with a total score of 100 maximum. While for data analysis, those are by describing pre-test result of experiment class, the post-test of experiment class, the pre-test of control class and the post-test of control class. To describe data from student's mathematics problem solving ability used descriptive statistic technique which includes average (mean), standard deviation, variance, maximum value and minimum value. Calculation is done with the help of SPSS program. Data analysis is done by using onepath Anavaand two-path Anava. But before testing the hypothesis with the data analysis, firstly tested the requirements analysis of the normality test and homogeneity 
test. After the prerequisite test is met, hypothesis test is performed.

\section{RESULTS AND DISCUSSION}

After the test was tested it shows the test result is valid and reliable with the result of 0.79 and 0.93. After ensuring the data is normally distributed then test data analysis.

Table 2 the two-path Anava test gain the ability to comprehend mathematics concepts.

\begin{tabular}{|r|r|r|r|r|r|}
\hline Source & $\begin{array}{r}\text { Type III } \\
\text { Sum of } \\
\text { Squares }\end{array}$ & df & $\begin{array}{r}\text { Mean } \\
\text { Square }\end{array}$ & F & Sig. \\
\hline $\begin{array}{r}\text { Corrected } \\
\text { Model }\end{array}$ & 0,589 & 5 & 0,118 & 10,61 & 0,00 \\
9 & 0 \\
\hline Intercept & 21,713 & 1 & 21,713 & $\begin{array}{r}1958, \\
404\end{array}$ & 0,00 \\
& & & & 0 \\
\hline Approach & 0,209 & 1 & 0,209 & 18,85 & 0,00 \\
& & & & 4 & 0 \\
\hline Ability & 0,334 & 2 & 0,167 & 15,06 & 0,00 \\
& & & & 4 & 0 \\
\hline $\begin{array}{r}\text { Approach } \\
*\end{array}$ & 4,552 & 2 & 2,276 & 2,053 & 0,13 \\
Ability & & & & & 3 \\
\hline Error & 1,353 & 122 & 1,109 & & \\
\hline Total & 30,426 & 128 & & & \\
\hline $\begin{array}{r}\text { Corrected } \\
\text { Total }\end{array}$ & 1,941 & 127 & & & \\
\hline
\end{tabular}

Table 3 the average Scheffe test of the ability to comprehend mathematics concepts for early mathematic ability factors.

\begin{tabular}{|c|c|c|c|}
\hline Ability (I) & Ability (J) & $\begin{array}{c}\text { The difference } \\
\text { of average } \\
\text { (I-J) }\end{array}$ & Sig. \\
\hline \multirow{2}{*}{ High } & Medium & 0,07380 & 0,017 \\
\cline { 2 - 4 } & Low & 0,15853 & 0,000 \\
\hline Medium & Low & 0,08473 & 0,002 \\
\hline
\end{tabular}

Based on the above table 2 shows that for the approach factor Fcalculated $=18,854$ is greater than Fcritical $=3,919$ at the stage of significance $\alpha=0,05$ with degrees of freedom $1 \mathrm{x}$ $122(0,95 \mathrm{~F} 1,122)$. Therefore, there is a difference in the ability to improve the concept of understanding ability between students who are given discovery learning model compared with students who are given a conventional approach.

Based on the above table shows that for the approach factor Fcalculated $=15,064$ is greater than Fcritical $=3,070$ at the stage of significance $\alpha=0,05$ with degrees of freedom $2 \mathrm{x}$ $122(0,95 \mathrm{~F} 2,122)$. There is a difference in understanding of student's math concept between high, medium and low students ability.

Based on the above table 3 , it is seen that for the interaction between the approach and ability factor is obtained Fcalculated $=2,053$ is smaller than Fcritical $=3,070$ at the stage of significance $\alpha=0,05$ with degrees of freedom $2 \times 122$
$(0,95 \mathrm{~F} 2,122)$. According to the data above shows that the interaction between the learning approach with the initial ability of mathematics students did not give a significant effect together on the improvement of ability the concept understanding ability of students. Difference in ability improvement, conceptual understanding ability is caused by different learning approaches used open because of student's math skill.

Table 4 the summary of two-path Anava test gain measures self-efficacy

\begin{tabular}{|r|r|l|l|l|l|}
\hline Source & $\begin{array}{r}\text { Type III } \\
\text { Sum of } \\
\text { Squares }\end{array}$ & df & $\begin{array}{l}\text { Mean } \\
\text { Square }\end{array}$ & F & Sig. \\
\hline $\begin{array}{r}\text { Corrected } \\
\text { Model }\end{array}$ & 0,197 & 5 & 3,946 & 5,084 & 0,000 \\
\hline Intercept & 12,645 & 1 & 12.645 & 1629,062 & 0,000 \\
\hline Approach & 7,106 & 1 & 7,106 & 9,155 & 0,003 \\
\hline Ability & 8,445 & 2 & 4,222 & 5,440 & 0,005 \\
\hline $\begin{array}{r}\text { Approach } \\
* \text { Ability }\end{array}$ & 3,261 & 2 & 1,630 & 2,100 & 0,127 \\
\hline Error &, 947 & 122 & 7,762 & & \\
\hline Total & 17,724 & 128 & & & \\
\hline $\begin{array}{r}\text { Corrected } \\
\text { Total }\end{array}$ & 1,144 & 127 & & & \\
\hline
\end{tabular}

Table 5 the average Scheffe test is a critical self-efficacy test for early mathematics ability factors.

\begin{tabular}{|c|c|c|c|}
\hline Ability (I) & Ability (J) & $\begin{array}{c}\text { The } \\
\text { Difference of } \\
\text { Average } \\
\text { (mean) J }\end{array}$ & Sig. \\
\hline \multirow{2}{*}{ High } & Medium & 0,04002 & 0,175 \\
\cline { 2 - 4 } & Low & 0,07977 & 0,007 \\
\hline Medium & Low & 0,03975 & 0,122 \\
\hline
\end{tabular}

Based on the above table 4 shows that for the approach factor Fcalculated=9,155is greater than Fcritical= 3,919at the stage of significance $\alpha=0,05$ with degrees of freedom $1 \times 122$ $(0,95 \mathrm{~F} 1,122)$. There is a difference in the increase of selfefficacy between students who are given a model of discovery learning compared to students who were given a conventional approach. Taking into account the average value of both groups can be concluded that the improvement of students mathematics critical thinking ability that are given discovery learning model significantly better than the students who were given a conventional approach.

Based on the above table 5, it is seen that for the interaction between the approach and ability factor is obtained Fcalculated $=2,100$ is smaller than Fcritical $=3,070$ at the stage of significance $\alpha=0,05$ with degrees of freedom $2 \times 122$ $(0,95 \mathrm{~F} 2,122)$. According to the data above shows that the interaction between the learning approach with the initial ability of mathematics students did not give a significant effect together on the improvement of ability critical thinking of student mathematicsof students. Difference in ability improvement, the critical thinking of students mathematics is 
caused by different learning approaches used open because of sthe initial of tudent's math skill.

The result of this study indicates that the average increases in the ability to understand the concept of mathematics student who are given discovery learning model is higher compared with students who were given a conventional learning.

In accordance with the allegations of writer that there is a difference in the ability to understand the understanding of mathematics concepts between students who were given discovery learning model with students who were given a conventional learning. Because learning is done by finding self-concept by the students so that learning is more memorable and impregnated students with more depth. Making it easier for them to search for possible solutions by using their mathematics ability. While in the conventional approach, the problem is always alien to the child, so the child is difficult to understand. If to understand the problem of the the child has difficulty, then to find the solution will feel more difficult, so the child can not develop the mathematics ability he has.

Furthermore, the factor of learning model and the student's early ability of mathematics do not have an effect on the improvement of comprehension ability of mathematics concepts, it can be seen from the result of study which shows that there is no interaction between the approach and the aerly ability of mathematics students in improving the ability of understanding the concept of mathematics.

The result of this study indicates that there is a difference of improving self-efficacy between studenst who were given discovery learning model with students who were given a conventional learning.the average (mean) of both groups shows that students who were given discovery learning model is higher compared with students who were given a conventional learning.

\section{CONCLUSION}

The result of this study indicates that the average increases in the ability to understand the concept of mathematics student who are given discovery learning model is higher compared with students who were given a conventional learning.

It is becauselearning is done by finding self-concept by the students so that learning is more memorable and impregnated students with more depth. Making it easier for them to search for possible solutions by using their mathematics ability.

Further, the factor of learning model and the student's early ability of mathematics do not have an effect on the improvement of comprehension ability of mathematics concepts.

The result of this study indicates that there is a difference of improving self-efficacy between studenst who were given discovery learning model with students who were given a conventional learning. the average (mean) of both groups shows that students who were given discovery learning model is higher compared with students who were given a conventional learning.

\section{REFERENCES}

[1] Hudojo, Pengembangan Kurikulum dan Pembelajaran Matematika. Malang: Universitas Negeri Malang.2005, pp. 107

[2] Suherman, E., dkk, Strategi Pembelajaran Matematika Kontemporer, Jakarta : Universitas Pendidikan Indonesia, 2003, pp.25

[3] Arends, R. I, Learning to Teach, 1994, pp. 386

[4] Bandura. A, Self-efficacy, Toward a Unifying Theory of Behavioral Change, StanfordUniversity, (online)(http://www.uky.edu/ eushe2/Bandura/ Bandura1977PR.pdf. 20 Oktober 2015)

[5] Tansil, S., Anindono, A., \& Evy, T, Reflected Appraisals dan Mathematic Academic Self-Efficacy pada Siswa SMA. Surabaya: Anima, Indonesian Psychological Journal 2009, vol. 24, No. 2, 183-188. (online)(http://repository.ubaya.ac.id. Diakses 20 januari 2016).pp.1

[6] Afrilianto, M. 2012. Peningkatan Pemahaman Konsep dan Kompetensi Strategis Matematis Siswa SMP dengan Pendekatan Metaphorical Thinking. Jurnal Ilmiah Program Studi Matematika STKIP Siliwangi Bandung Vol.1,No.2(http://ejournal.stkipsiliwangi.ac.id/index.php/infiniy /article/view/19/18 accessed 01 October 2014).

[7] Chukwuyenum, A. N. 2013. Impact of Critical thinking on Performance in Mathematics among Senior Secondary School Students in Lagos State. IOSR Journal of Research \& Method in Education (online), Vol. 3. Issue 5,(http://www.iosrjournals.org/iosr-jrme/papers/Vol-3\%20I.pdf, accesed 29 April 2014) 